\title{
Determining Business Interruption Losses for Small Business
}

\author{
Denis O. Boudreaux ${ }^{1}$, Praveen K. Das ${ }^{1}$, S. P. Uma Rao ${ }^{1} \&$ Nancy Rumore ${ }^{1}$ \\ ${ }^{1}$ Department of Economics \& Finance, B. I. Moody III College of Business Administration, University of Louisiana \\ at Lafayette, Lafayette, U.S.A. \\ Correspondence: Praveen K. Das, Department of Economics \& Finance, B. I. Moody III College of Business \\ Administration, University of Louisiana at Lafayette, Lafayette, LA 70504, U.S.A. E-mail: pkd8947@louisiana.edu \\ Received: February 3, 2015 \\ Accepted: February 18, 2015 \\ Online Published: July 6, 2015 \\ doi:10.5430/ijfr.v6n3p56 \\ URL: http://dx.doi.org/10.5430/ijfr.v6n3p56
}

\begin{abstract}
Business interruption insurance often referred to as lost profit or loss income insurance is written and purchased to protect a business for when its operations are interrupted and income is reduced due to the occurrence of a covered peril. The determination of the actual economic loss can be difficult and controversial. The loss computation depends on the determination of what the sales would have been had there been no loss event and what expenses should be subtracted from the estimated sales. In this paper, we discuss the issues with business interruption claims, and theoretically correct approach to measure a firm's loss due to an interruption in operations from a covered peril. We present an example showing calculation of economic loss due to business interruptions.
\end{abstract}

Keywords: business interruptions losses, calculation of economic loss

\section{Introduction}

The economic impact of major disasters such as hurricanes, wildfires, floods, earthquakes, act of terrorism, etc. are considerable. For example, Burby (2006) estimates economic losses from Hurricane Katrina to be more than \$200 billion. According to a study commissioned by Louisiana Recovery Authority, the economic costs of damage caused by Hurricane Rita exceeded $\$ 10$ billion. The tragedy of September 11, 2001, when the twin towers of the World Trade Center came down, cost the insurance industry over 36 billion dollars (Hartwig, 2006). The Deepwater Horizon disaster in 2010 had a strong impact on economy of Gulf states and resulted in multi-billion dollar loss for business in sectors such as tourism, commercial fishing, and oil industry. Though these calamities include lost wages, property damage, etc., Mowbray (2006) state that most of the payout for damage claims is from business interruption filings. Business interruption insurance is a type of commercial insurance that provides protection to business against loss of income arising after a disaster. In other words, business interruption insurance is designed to insure business against losses arising from its inability to continue its normal business operations after a disaster (Hammond, 1999). Business interruption insurance is not a recent phenomenon but was used by traders four thousand years ago. The Babylonians developed a system of business insurance where a merchant paid the lender an additional fee in exchange for getting the right to cancel the loan in the event of disaster.

According to American Insurance Association (AIA), business interruption insurance is a part of firm's commercial insurance policies and business owner's policies. AIA states that business interruptions had four critical elements: 1) it is only triggered if there is substantial physical damage that business has to suspend its operation, or if the damage prevents customer or employees from gaining access to the business. 2) Most policies have a waiting period. 3) Business interruption coverage is limited. 4) Coverage is only for period necessary to get the business back in operation. A sample business interruption policy is shown in Exhibit I. According to Donald Lesser of Lesser Law Group, the standard business interruption policy has number of requirements that business must meet before coverage comes into play. For example, there must be physical damage to the property located at the address specified in the policy. This damage must be caused by incident or disaster covered in the policy and must cause interruption in business operations. The economic damages to business include lost income from cessation of business operations. The insurance policy may also include provision to compensate business for extra expenses due to peril until it gets back to its pre-loss income level. 


\section{The Loss Model}

In order to design our loss model, we first need to identify the loss time period. Next, we need to measure the lost sales attributed to business interruption. Once lost sales are determined, we then estimate the expenses which would have been incurred to produce that lost sales. The amount of depreciation that would have occurred must also be estimated. Then, a pro-forma statement needs to be prepared to measure firm's operating loss resulting from firm's decrease in cash flows. Covered fixed costs and "extra expenses" are to operating loss to get the firm's total loss. Covered fixed costs are those costs that continued during the loss period and were paid by the firm. The "extra expenses" are those expenses incurred by the firm to reduce the damages due to business interruption. The model to determine loss can be are shown below:

$$
\text { Total Payable Claim for Disruption }=\mathrm{DCFO}+\mathrm{EE}+\mathrm{FC}
$$

Where:

DCFO is the Difference in Cash Flows from Operations

EE is the "extra expenses" occurred to reduce the damage

FC is Fixed costs that continued to occur during loss period.

$$
\text { DCFO }=\text { ECFOWI }- \text { CFOWI }
$$

Where:

ECFOWI is Expected Cash Flow from Operations Without Interruptions

CFOWI is Cash Flow from Operations with Interruptions but excluding certain expenses that are reimbursed.

\section{Case}

The operating facility including plant and machinery of Acme Manufacturing Inc, a privately owned manufacturing firm, were completely destroyed by an insured peril; an explosion and fire. However, their warehouse that stored inventory was a separate building and was only partially damaged and half of the inventory was lost which is valued at $\$ 10,749,400$. The warehouse's roof now has a hole so the undamaged inventory will have to be immediately removed to a temporary storage building. The cost to stop further damage to the warehouse and move the inventory to a temporary storage including rent until it was sold was $\$ 1,400,000$. Acme manufactured disposable bags for popular vacuum cleaners. Acme is the primary manufacturer and supplier of vacuum bags to a major vacuum manufacturing company located near its facility in Mississippi. Also, Acme sells bags directly to retail stores around the country and had a web page for individual customer orders. Over $99 \%$ of the bags were for customers living in the USA.

The firm had to completely cease its manufacturing operations until the plant could be rebuilt and new machinery reinstalled. The firm, an S Corporation prepared and maintained only one set of financial statements which were for tax purposes. The most recent yearly income tax return (1120S) which can and should be used as the basis to prepare a common size income statement is found in Exhibit II. Also, the explosion and ensuing fire occurred on January 1, 2010 the first day of the fiscal year and the plant was idle for the holiday (no lost income for the day). It is now in early 2011; the firm did recover and restart their operations on January 2, 2011 so the period the firm could not operate is one year.

\section{Measuring the Damages}

The first step in the interruption loss analysis is to determine the loss period. It took one year for the facility to be rebuilt and new machines installed and operations to resume so the loss period is exactly one year.

The second step in analyzing the economic loss to a firm for loss of profit/income is to calculate the firm's lost sales - reduction in sales. The analyst should review the company's recent sales results found in the latest income statement, macro economic data, industry detailed data and specific firm information to calculate what the sales would have been. Acme regularly prepares pro forma financial statements for planning purposes. A marketing study was accomplished ten months before the explosion to predict future sales to accommodate the pro formas (See Exhibit II). An analyst will use the marketing study and will also review the firm's historic sales and the operating and competitive environments to estimate what the sales would have been in 2009 had there been no peril. Acme annual sales for 2006-2009 shown by customer type are presented in Exhibit III. Using the sales data, the analyst estimates that the sales would have been $\$ 272,900,000$ (See Exhibit IV). 
The third step is to determine the cash expenses that would have occurred to generate the loss sales of $\$ 272,900,000$. To measure variable costs, a simple and effective technique is the percentage of sales method. The firm's previous year's income statement shown as a percentage of sales which is typical of the firm's expense ratios is presented in Exhibit V. The 2010 Income Statement that represents what the firm would have earned had there been no disruption is presented in Exhibit VI. For the expenses that are variable, these are estimated using the same percentage of sales of 2009 rates. The firms planned on increasing compensation to officers by $2 \%$ and to increase the salaries by $3 \%$. There were no plans on any other changes that would impact fixed costs, so those expenses that are fixed are estimated using 2009 values.

The last step is to compare what the operating cash flows would have been had there been no interruption to the actual operating cash flows from operations that did occur for the loss year. The difference is the loss in operating cash flows.

After calculating the loss in cash flows, the covered expenses that occurred to reduce the potential loss and the extra fixed expenses that did occur because of the peril are determined. The sum of the three is the amount Acme should be paid by its insurance company for its coverage under the loss profit or disruption insurance policy (See Exhibit VII).

\section{Conclusion}

The intentions of the insurance contract are to restore the insured to the same position before the loss occurred. This includes tangible assets and lost profit/income. It is well established in the financial literature that cash flow is the most theoretically correct variable to measure a firm's value. Theoretically, it follows that it should be the measure of lost cash flow that should be used to measure the loss/damages to a firm for an interruption in operations. To properly measure the difference or reduction in cash to the firm, an estimate of what the expected cash flows would have been had there been no peril and interruption in operations is compared to the actual cash flow from operations. The difference is part of the loss covered under lost profit or interruption insurance. To the loss in operating cash flow, the covered continuing fixed costs and expenses that occurred to reduce the damages are added. The paper presents a theoretically correct model to measure loss for business interruption and a practical example.

\section{References}

American Insurance Association. Business Interruption Insurance. Retrieved April 20, 2015 from http://www.aiadc.org/AIAdotNET/docHandler.aspx?DocID=287081

Burby, R. (2006). Hurricane Katrina and the Paradoxes of Government Disaster Policy: Bringing about Wise Governmental Decisions for Hazardous Areas, pp. 171-191

Hammond, R. (1999). Underlying Principles of Business Interruption Insurance. Retrieved from http://library.findlaw.com/1999/Jun/1/127909.html

Hartwig, R. (2006). 9/11 and Insurance: The Five Year Anniversary. Retrieved from http://server.iii.org/yy_obj_data/binary/760752_1_0/September\%2011\%20Anniversary.pdf

Lesser, Donald. Getting (Back To) Business Interruption Insurance. Retrieved April 20, 2015 from http://www.uphelp.org/library/resource/getting-back-business-interruption-insurance

Mowbray, Rebecca. (2006, September 17). World Interrupted. The Times-Picayune, p. 1. 


\section{EXHIBIT I}

ACME MAUFACTURING, Inc.

INCOME STATEMENT, FORM 1120S

In 000 's of $\$$

December 31, 2009

Revenue
Cost of Goods ${ }^{1}$

Gross Profit

Compensation of Officers

Salaries

Repairs and maintenance

Bad Debt

Taxes and Licenses

Interest

Depreciation

Advertising

Pension

Other

Total Deductions

Taxable Income

Taxes (40\%)

Net Income

ADD Back Depreciation

Cash Flow from Operations (CFfO)
\$ $248,993.0$

$\underline{149,395.8}$

$99,597.2$

$2,489.9$

$22,409.4$

$9,959.7$

0

24.9

$9,959.7$

$19,919.4$

$12,449.6$

0

$\underline{497.9}$

$\$ 77,710.5$

$\$ 21,886.7$

$\$ 8,754.7$

$\$ 13,132.0$

$\$ 19,919.4$

$\$ 33,051.4$

$\begin{array}{ll}\text { Beginning Inventory } & \$ 20,997.7 \\ \text { Purchases } & \$ 174,496.5 \\ \text { Ending Inventory } & \$ 21,498.8 \\ \text { Direct Labor } & \$ 24,599.6 \\ \text { Cost of Goods } & \$ 149,395.8\end{array}$




\section{EXHIBIT II}

FEBRUARY 2009 MARKETING STUDY

FORECASTED SALES

In 000 's of \$

\begin{tabular}{llll}
\cline { 2 - 3 } YEAR & 2009 & 2010 & 2011 \\
TOTAL SALES & & & \\
& 248,500 & 269,660 & 292,580 \\
SALES: MANUFACTURER & 144,130 & 153,706 & 163,845 \\
\% OF TOTAL & $58 \%$ & $57 \%$ & $56 \%$ \\
SALES: RETAILERS & 44,730 & 48,539 & 52,664 \\
\% OF TOTAL & $18 \%$ & $18 \%$ & $18 \%$ \\
& & & \\
SALES: ONLINE & 59,640 & 67,415 & 76,071 \\
\% OF TOTAL & $24 \%$ & $25 \%$ & $26 \%$
\end{tabular}

${ }^{1}$ Sales will increase $8.5 \%$

EXHIBIT III

SALES COMPOSITION

In 000 's of $\$$

YEAR

TOTAL SALES*

PERCENTAGE CHANGE

SALES: MANUFACTURER

$\%$ OF TOTAL

PERCENTAGE CHANGE

SALES: RETAILERS

$\%$ OF TOTAL

PERCENTAGE CHANGE

SALES: ONLINE

$\%$ OF TOTAL

PERCENTAGE CHANGE
2007

210,150

$8.31 \%$

130,293

$62.0 \%$

$4.95 \%$

44,132

$21.0 \%$

$3.95 \%$

35,725

$17.0 \%$

$24.95 \%$
2008

229,064

$9.00 \%$

137,438

$60.0 \%$

$5.48 \%$

45,235

$19.7 \%$

$5.48 \%$

46,391

$20.3 \%$

$23.1 \%$

$29.9 \%$
57,421

2009

248,993

$8.70 \%$

145,025

$58.2 \%$

$5.52 \%$

46,547

$18.7 \%$

$2.90 \%$

$23.77 \%$

*Total Sales for 2006 was \$194,026 


\section{EXHIBIT IV}

\section{SALES ESTMATION}

In 000 's of $\$$

Sales for $2010=$ Manufacturer Sales ${ }^{1}+$ Retailers Sales $^{2}+$ Online Sales $^{3}$

Sales for $2010=145,025 * 1.057+46,547 * 1.04+57,421 * 1.24=272,900$

${ }^{1}$ Growth in Manufacturer Sales is $5.7 \%$ found by Vacuum Manufacturers' sales increase.

${ }^{2}$ Growth in Retailers Sales is found by averaging the past three years.

${ }^{3}$ Growth in Online Sales is found by averaging the past three years.

Economic data for the year 2010 shows that the U.S.A. had an average year of economic growth as GDP grew at $3.85 \%$. Overall, vacuum cleaner sales for the manufacturing company Acme supplies to were very good as they had an increase in sales of 5.7. There were no significant developments by Acme competitors, so sales for Acme would have been similar to previous years except for potential increases due to sales by the contracted manufacturer, increase in demand from retailer customers and an increase in the on line purchases. Based on retail firm orders that could not be filed and on line purchase requests, sales to retail customers would have increased by approximately $4 \%$ and on line purchases would have increased by over $24 \%$ which is the average growth rates for the past three years. 


\section{EXHIBIT V}

ACME MAUFACTURING, Inc.

INCOME STATEMENT, FORM 1120S

PERCENTAGE OF SALES

In 000 's of $\$$

December 31, 2009

Revenue

Cost of Goods ${ }^{1}$

Gross Profit

Compensation of Officers

Salaries

Repairs and maintenance

Bad Debt

Taxes and Licenses

Interest

Depreciation

Advertising

Pension

Other

Total Deductions

Taxable Income

Taxes $(40 \%)$

Net Income

ADD Back Depreciation

Cash Flow from Operations (CFfO) $\underline{\%}$

$\$ 248,993.00 \quad 100.00$

$\underline{149,395.80} \quad \underline{60.00}$

$99,597.20 \quad 40.00$

$2,489.90 \quad 1.00$

$22,409.40 \quad 9.00$

$9,959.70 \quad 4.00$

$0 \quad 0.00$

$24.90 \quad .010$

$9,959.70 \quad 4.00$

$19,919.40 \quad 8.00$

$12,449.60 \quad 5.00$

$0 \quad 0.00$

$\underline{497.90} \quad \underline{.200}$

$\$ 77,710.50 \quad 31.21$

$\$ 21,886.70 \quad 8.79$

$\$ 8,754.70 \quad 3.52$

$\$ 13,132.00 \quad 5.27$

$\underline{\$ 19,919.40 \quad \underline{8.00}}$

$\$ \quad 33,051.40 \quad 13.27$
$1 \quad$ Beginning Inventory

Purchases

Ending Inventory

Direct Labor

Cost of Goods
$\$ 20,997.70$

$\$ 174,496.50$

$\$ 21,498.80$

$\$ 24,599.60$

$\$ 149,395.8$
8.43

70.08

8.63

9.88

60.00 


\section{EXHIBIT VI}

ACME MAUFACTURING, Inc.

POST FORMA INCOME STATEMENT

PERCENTAGE OF SALES

In 000 's of $\$$

FOR December 31, 2010

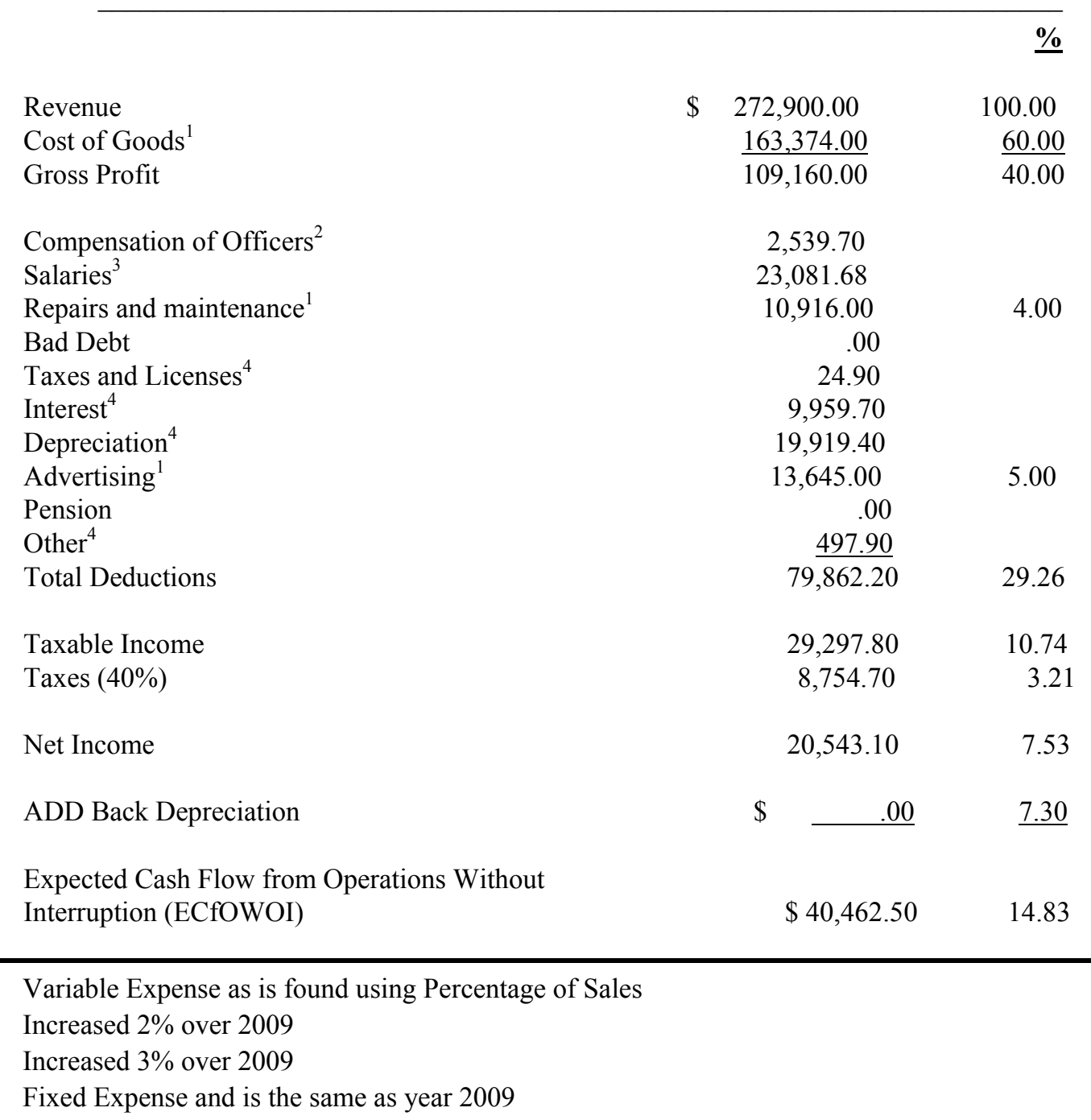

\section{EXHIBIT VII}

ABC MAUFACTURING, Inc.

INSURANCE OBLIGATION UNDER DISRUPTION INSURANCE POLICY/LOSS UNDER DISRUPTION INSURANCE POLICY FOR 2010

1. Expected Cash Flow from Operations Without Interruption (CFfWOI)

2. MINUS Actual Cash Flow from Operations With Interruption (CFfOWI)

3. Difference in Cash Flow from Operations (CFfO)

4. Insurance Proceeds for Salaries,Expenses/Repairs \& Rent TOTAL
$\$ 40,462.50$

$-1,970.90$

$42,433.40$

$3,600.00$

$\$ 46,033.40$ 